\title{
THE ROLE OF WILDLIFE ON FOREST LAND IN WESTERN CANADA ${ }^{1}$
}

\section{By I. MCTAGgART COWAN2}

The role of wild animals in the lives of men in Canada has changed vastly in the last 100 years. To the native North American, game was food and all edible forms were used for this purpose. At the same time, by-products were converted into essential articles for living. This same role persisted during the early stages of white colonization. Later, as communities developed and more intensive agricultural use of the land substituted a more stable food supply and removed the wild game from immediate contact with many men, market hunting flourished and game animals and fur bearing animals were taken for sale. Very shortly a diversion appeared in our concept of wildlife values, recreational hunting evolved as the highest use to which the large game species could be put, and all those forms of wildlife in each region capable of providing recreational hunting were afforded protection from commercial use. This change has been a gradual one. Conceived in the early centres of urbanization it has spread gradually, with the increasing density of human population, until it has become the accepted concept over the southern half of Canada. In the northern half game is still looked upon as essentially food and clothing, but market hunting is generally prohibited. Everywhere in Canada the fur bearing mammals are recognized as a commercial crop, and across the nation, the migratory waterfowl are regarded as serving their best use in providing recreational hunting.

It should be borne in mind, also, that a large part of our population has evolved beyond the stage of extracting value from wildlife only as a crop, and that they derive pleasure from wildlife alive to a degree that they contribute quite largely to the secondary values of this resource.

These several views of the best use of the wildlife resources of Canada must be appreciated in the discussion of any overall land use plan upon which wildlife is a recognized asset. At least four additional basic facts of wildlife production must be emphasized before it is pertinent to consider the place of wildlife in multiple use planning on forest land.

The first of these is that all wildlife species have well defined ecological preferences in the form of the plant cover they inhabit. They have very precise needs, and just any old land that does not happen to be of interest to the forester, rancher or anyone else, may well be no good for game raising either. The nature of the plant formation, and the stage in its sequence toward the climax type of vegetation, directly govern the species of wildlife that can occur and the numerical abundance of these. Of the four great plant formations that characterize western Canada, large game mammals became exceedingly numerous only in the two in which the dominant plants of the climax were palatable, nutritious and available. These are the Prairie

\footnotetext{
1 Presented at the annual meeting of the Canadian Institute of Forestry, Banff, Alberta, October 11-13, 1951.

2 Professor of Zoology, Department of Biology, University of British Columbia.
} 
Grasslands and the Arctic Tundra formations. It was on these that the great herds of bison and antelope and the migrating bands of barren ground caribou fed. The two formations in which there is a Coniferous climax of species largely unpalatable and out of reach, the Taiga and the Montane Forest formations, are and always have been relatively unproductive of large game.

The moose, elk, black-tailed and white-tailed deer, mountain goat and bighorn sheep: the marten, fisher, wolverine, lynx, red fox, timber wolf, beaver and short-tailed weasel, all fall into the category of forest wildlife, but they in turn can be subdivided on the basis of the successional stage in which they reach greatest density. Thus the moose, elk, black-tailed and white-tailed deer, fox, Iynx and beaver reach their greatest numbers during the deciduous tree and shrub phases early in the successional history of the forest. Similarly in a subclimax or climax forest, these species occur primarily along the forest edge, be that local, as adjoining rivers or lakes ,or be it widespread as where the forest abuts on the alpine or arctic tundra or the prairie grasslands.

The bighorn and goat enter the boundaries of the Montane Forest only where the earliest grass and shrub aspects occur, while elsewhere they are animals of the alpine grasslands or forest edge.

The mountain caribou is unique in requiring juxtaposition of two plant formations in climax stage. The alpine tundra in summer and overmature climax spruce forests for the winter.

The fisher, lynx and beaver are most numerous where parkland and conifer forest intermingle and the marten alone is inescapablly bound to the subclimax and climax coniferous stands of both Taiga and Montane Forest formations.

The second important consideration in the maintenance of wildlife values of forest land is that of maintaining or producing optimum interspersion of stands of different ages. Extensive evenage stands, be they in the shrub stage of early forest regeneration or in the mature climax type, are relatively unproductive of wildlife. Our studies of the Columbian black-tailed deer on Vancouver Island have emphasized the vital part played by islands of mature timber scattered through extensive deforested areas. These islands, usually of unmerchantable trees on rocky or boggy sites, serve as nuclei of game survival during the winter months. The food-producing potential of the surrounding deciduous area is only utilized within a narrow belt around the sheltering timber and the great tracts remote from such shelter carry no deer in the winter time. Other studies we have made, of the changing food values within a forest during the first seventy years of its regeneration, have thrown more light on the importance of diversification of forest type in the maintenance of wildlife populations. It has been found that while crude protein and ether extractives were provided in greater quantity by the young forest, the mineral content and ascorbic acid content of the available parts of the older forest are higher. A proper nutritional balance therefore may be dependent upon access to forest stands of greatly varied ages.

The third factor of major concern is the adequacy of food supply during 
the periods of greatest scarcity. In the mountainous parts of Alberta and British Columbia where steep slopes are the rule, most game mammals ascend the mountains to summer at higher altitudes. Here there are vast acreages of almost unutilized big game range. When the winter snows accumulate however, they descend to winter ranges in the valley bottoms or on the more exposed highly insulated, wind-blasted lower slopes. Here, concentrated on ranges in use since primitive times, they fight their way through the winter. Unfortunately, all too often these have been appropriated for agricultural tillage or have been over-pastured with domestic stock during the summer months. When such a situation arises the game, already restricted to less than one per cent of the area of the available range, finds even that deprived of its carrying capacity. In this manner, by the denial of very small range areas for the winter use of game, entire forest regions may be virtually depopulated.

Throughout the mountainous west the weakest link in the food chain is that of the late winter and early spring. Concentration on the needs of this period is imperative and should be regarded as one of the primary concerns of the forester charged with the administration of grazing rights for domestic livestock on wild ranges valuable also for game production.

Finally we must have an understanding of the consequences that may accrue through neglect of the cardinal responsibility to place a high priority on the maintenance of the key winter ranges. In these northern latitudes a loss of weight by wintering big game animals is almost universal. Even our captive experimental deer, when on an ad libitum diet of wild game foods, lost weight. If then, to the normal insufficiency of winter nutrients together with extreme cold, or deep snow, is added scarcity of forage plants, the consequences are apt to be lethal, and winter kill occurs. Such losses are not due to starvation alone but often result from parasitism or disease rendered serious by malnutrition. It is known also (Cheatum \& Severinghaus 1950, Cowan, 1950) that not alone does the overwintering stock suffer losses, but the fecundity of the residual brood stock is lowered and the ability of the stock to recover impaired.

\section{The Priority Position of Wild life on Forest Land}

The value of forests is too frequently estimated solely upon the value of trees, based in turn upon the value of lumber and other wood products. Forests have other real values - in protecting watersheds, in providing recreation (including hunting), and as a source of raw furs. These values have seldom been considered, except philosophically, because of the absence of accurate data.

Wood and wildlife are two of the most important resources in large areas of Canada. It goes without saying that on good forest sites where timber values are high, there are seldom other values approaching these. On such areas, wildlife production is incidental to timber and wherever the two interests clash irrevocably, the timber interests should take priority. However, clashes of interest are seldom insoluble, and it is possible to plan for the production of large crops of wildlife, both game and fur, on high quality 
forest land. This has been and is the case on Vancouver Island, British Columbia, where an annual crop of seventy thousand sooty grouse and five thousand deer is taken from some of the most productive forest land in the Province. Problems of conflict do arise and are discussed later.

On the other hand there are in British Columbia 249,000 square miles, two-thirds of the provincial area, not currently considered as capable of producing timber of commercial quality (Druce, 1949). On this land, wildlife is frequently the most important resource.

Some recent studies by the University of British Columbia and the B.C. Provincial Game Commission have made available figures of wildlife values on some of the forest land of central and northern British Columbia.

The Cariboo District of central British Columbia in 1950 yielded a harvest of more than 2,000 moose. This it has been doing annually for about the last ten years. Careful computation of the direct contribution of this harvest to the region places it close to $\$ 450,000$ per annum. This is a very considerable financial return from a crop taken from otherwise unproductive land.

R. Y. Edwards (Unpublished thesis, University of British Columbia) has made some calculations of the raw fur crop produced by eight trap lines within 16 miles of Fort Nelson, British Columbia, with a total area of 845 square miles. For the purpose of computations, the raw fur values used have been mean prices over the 19 years 1929-1947, a value little more than half current market value. The annual value is compounded at 3 per cent interest over an assumed forest cycle growth period of 100 years. On this basis the fur value of these 8 trap lines amounts to $\$ 8,345,671$ or approximately $\$ 10,000$ per square mile.

Wildlife values such as these, from otherwise unproductive forest land, are large enough to justify careful attention to the special requirements of this source of forest revenue. There is need of further and more refined studies of the value of the wildlife resource on wild lands of all different ecologic types in order that some progress can be made in the development of provisional wildlife yield tables that will assist in priority assessments.

Referring again to the Fort Nelson area, it is most pertinent to consider the type of fur contributing to the harvest. Ninety-two per cent of the fur values were contributed by three of the so-called fine fur species - beaver, marten and lynx. These are primarily climax and late deciduous stage species and their maintenance is dependent directly upon the survival of the appropriate forest stage. Large scale logging, or destruction of the forest by fire, would eliminate the marten and probably the lynx, and replace them with the much less valuable coarse fur species in greatly reduced densities.

\section{ACCESS AND WILDLIFE UTILIZATION}

The big game and resident game bird stocks of the Canadian west are harvested very unevenly. Vast areas of land upon which big game may be relatively abundant yield no harvest at all year after year. Quite obviously this may be a most undesirable situation. In some instances the unharvested species suffers no damage and the crop merely stands as one lost. In many 
other instances, however, the game population under such circumstances tends to exceed its food supply to the end that the region suffers grave ecological changes and a drastically lowered carrying capacity ensues. The game-producing potential of the region is impaired for many years to come. The ramifications of situations of this kind may take peculiar directions as when an over-abundant elk herd wipes out the reproduction of willow and aspen and thus eliminates the replacement of essential beaver foods.

For the most part the unevenness of harvest results from facility of access. It has been shown that few hunters penetrate more than a mile from an auto road and almost none two miles from one. Therefore, where there are very large tracts of land with little or no access, where a crop is going unharvested while pressures on more accessible areas may be excessive, it is valuable to encourage other methods of distributing hunter effort more widely. The presence of competent guides has a very useful purpose in this connection, as does in some cases the use of aircraft for transportation to remote lakes. The latter consideration though is fraught with dangers of control and requires careful regulation. While lack of access facilities can and does restrict the game harvest and promotes undesirable distribution, too easy access can be even more serious.

Modern truck logging operations leave behind them excellent roads, that often intersect the logged areas at intervals of less than a mile. In parts of the logged areas of eastern Vancouver Island abandoned logging railroad grades have been converted into roads for reforestation and protection use. On some such areas there are now so many roads that it is impossible for a deer or a grouse to get a quarter of a mile away from a road. Here the hunters cruise the area in automobiles and, with unlimited visibility across the stumpland, a deer that escapes has a charmed life indeed. Where these conditions obtain, the right of public access during the hunting season may have to be restricted to certain key roads. If this is not done, overhunting almost inevitably results and game stocks decline.

In the mountainous parts of western Canada the bulk of the fur crop is taken in the remote areas but the main recreational uses of big game, upland game, birds and waterfowl are and probably will continue to be centred on areas close to civilization and it is on them that management must be concentrated.

\section{Game Damage}

Certain species of wildlife feed upon forest trees or their seeds and may destroy or damage sufficient of them to be of economic importance. It is not my purpose to treat this aspect of wildlife-forest relationships exhaustively but the situation must be recognized.

The most damaging species in western Canada is the white-footed mouse (Peromyscus maniculatus). The efficiency with which this mouse searches out and destroys the seeds of Douglas fir and some other trees is such that reforestation by seeding becomes economically impossible. This mouse is of little value in the wildlife economy on high quality forest land and no valid abjection to its control by poisoning can be made. However, such poisoning 
operations should be conducted with due safeguards to more valuable species. Porcupines, red squirrels and even bears have occasioned damage to growing trees that has been serious locally, but of more general concern is the damage done by blacktail deer, whitetail deer and by sooty grouse.

In some parts of British Columbia yellow pine (Pinus ponderosa) seedlings have been stunted or killed by deer browsing and on Vancouver Island young Douglas firs are particularly palatable to deer. On relatively poor growing sites a heavy deer population may retard forest regeneration by removing the leader from a large proportion of the trees each winter. The most serious damage occurs in forest types where large amounts of Usnea are simultaneously available to the deer. Adams (1951) has found that in parts of Montana up to 84 per cent of the Ponderosa pine seedlings and 65 per cent of the Douglas fir seedlings were killed by whitetail deer. It is probable that the same situation exists fairly widely.

Somewhat similar damage is sometimes caused to young Douglas fir seedlings by the sooty grouse. In the early spring this bird descends to the deforested areas from its mountain top winter range. In many areas its arrival coincides with the activities of the planting crews of the British Columbia Forest Services reforestation programme. The grouse finds succulent young trees of just the right height, spaced at very convenient distances, and takes advantage of the offering. Some are seriously damaged by leader removal but often more of them are uprooted.

Damage of the kinds outlined quite understandably weighs importantly in the attitude of the forester to wildlife. Efficient and economically feasible methods of protecting trees from game damage have yet to be developed. Discovery of such methods are a most urgent need if joint use programmes involving game and forestry are to prosper.

A remotely related type of damage that still plays an important role is that caused by sportsmen to forests and to equipment left on logging operations. The control of this damage rests directly with the hunter.

\section{National AND Provincial Parks}

The larger national and provincial park areas comprise a special aspect of forest management. The first concept of these areas was that they should remain untouched by human change and truly represent the natural state of the wilderness. The only conceded modification was for the construction of roads and trails to provide suitable access.

People are interested in animals alive and unafraid and the wildlife of such park areas constitutes one of the most important assets. Unfortunately it has proven most difficult to really leave nature alone to take its course. Forest fires are perfectly natural, as are outbreaks of pine needle-miner and pine bark-beetle, but if no attempt to control these is made the scenic values of the park region may be impaired. Similarly the overabundance of large game animals is a perfectly natural happening but the consequences are detrimental to other ideals of the park concept. 
Normal forest aging is another natural condition and one important in maintaining a full range of ecological circumstances. For instance, it is becoming increasingly evident that large tracts of overmature forest are necessary for the successful wintering of mountain caribou, one of the most desirable but delicately adjusted of the big game species. The marten and wolverine also require large tracts of mature or nearly mature conifer forest. Where such wildlife is of importance, the forester must learn to curb the impulse to regard overmature forests as an insult to his art.

On the other hand, the consequences of control of forest-destroying agents are a gradual maturing of all forest types to the ultimate end of a uniform climax stand. This, as we know, is an undesirable condition if an abundance and variety of big game is sought, but is conducive to the development of an abundance of the fine fur animals. Diversification of age is desirable but it is doubtful whether it should be fostered artificially.

However, it appears to me that all human influences should be maintained at the lowest point practicable, but that final decision as to what, if any, economic uses are to be made of the resources of the park for purposes other than non-destructive recreation pursuits cannot be decided upon on general terms without reference to local circumstances. First priority should go to scenic values and the presence of healthy, reasonably approachable animals, and nothing should be allowed to impair these.

\section{Discussion}

It has been truly said that every type of wild land can be made to yield some wildlife value, and this is particularly true of the forests of western Canada. However, the game mammals here are harvested on the easily accessible areas, and as road construction has not yet been undertaken with the sole purpose of bringing game within reach, it follows that big game and small game hunting takes place close to existing roads and settlements. In British Columbia the heaviest hunting is concentrated in the valuable timber lands of Vancouver Island. This situation produces some conflict between sportsmen and lumber operators but has not proven too difficult to resolve. However, it also makes the fire hazard attendant upon hunting activity particularly serious and some interruption of early autumn hunting seasons has inevitably occurred. Here, as in all valuable timber lands, the wildlife has to take second place to timber. Nevertheless, even here the game values are high and stand as an important annual return from land that would otherwise be unproductive between the far removed timber harvests.

In the grazing areas game survival on very large forest tracts frequently rests directly on the intensity of use of small, key winter ranges by livestock. There is a growing awareness of this situation by foresters in charge of grazing and timber rights, but wildlife management has lagged far behind forestry in public awareness, and in establishing its position in the national economy.

In a large proportion of western Canada forest land timber is of no market value and here wildlife is the most important product and should be given primary consideration. The largest part of the unproductive scrub 
forests is too far removed from roads to bear heavy hunting pressure. In all of them, however, the big game is important as food and the fur-bearing mammals as a means of livelihood for many of the residents. Annual fur yields sometimes exceed a dollar an acre. Recognition of the potential of this resource is a requisite of the sound management of any forest area but before we can achieve a higher degree of integration of wildlife management into land use planning, advance in the following directions must occur:

1. Increased knowledge of the precise needs of wildlife on various types of forest and rangeland.

2. Knowledge of possible yields.

3. Techniques for the control of game damage on valuable trees.

4. Better organized liaison between forester and wildlife manager.

5. More foresters and game managers with an ecological conscience extending to the entire forest, not merely the trees or the game.

\section{Literature Cited}

Adams, L., 1951, White-tailed deer browaing on natural conifer seedlings, Research Note No. 105, Northern Rocky Mountain, For. \& Range Sta. 3 pages.

Cheatum, E. L. \& Severinghaus, C. W., 1950. Variations in fertility of white-tailed deer related to range conditions. Trans. 15th N. Amer. Wildlife Conf.: 170-190.

Cowsn, I. Me'T., 1950, Some vital statistics of big game on overstocked mountain range Trans. 15th N. Amer. Wildlife Conf; 581-589

Druce, E., 1950, Forestry Outline in the Wealth of British Columbia, Proceedinga, Second Resources Conference, Province of British Columbia pp. 129-155. 